\title{
'N PLAN VIR DIE BEPALING VAN PASIËNTAKUUTHEIDSVLAKKE VIR VERPLEEGKUNDIGE POSTEBEPALING
}

\author{
AJ van Wyk en ME Muller
}

\section{OPSOMMING}

Die bestudering van pasiëntakuutheidsvlakplanne (PAVS) vir verpleeghundige postebepaling vir binnepasiēnte is deur middel van in verkennende, bestrywende en instrumentele studie binne kontekstuele verband gedoen. Met die literatuurstudie as agtergrond is in pasiëntakuutheisvlakplan (PAVS) ontwerp volgens die neergelegde kriteria ten einde data te kan bekom vir verpleegkundige postebepaling.

Hierdie studie is in a privaatnavorsingshospitaal in Johannesburg gedoen. Al die pasiente en verpleeghundiges (eerste- en tweede-in-bevel) is ten tye van die navorsingsperiode betrek. Die PALS-instrionent is deur die navorser ontwerp en onder begeleiding van die navorser, in sewe onderskeie verplegingseenhede in die hospitaat ge implementeer. Die instrument is as hoogs betroubaar bewys $(p=0,999)$.

Die verskal tusssen verpleegkundige postebepalings soos deur die aanbevole PAVS-instrument bepaal, en dié wat by wyse van in pragmatiese, subjektiewe benadering (werklike) dew die verpleegdiensbesturder van die hospitaal is, toon statisties onbeduidende verskille. Die lotaal verskil vir alle verplegingseenhede iussen die aanbevole en werklike verpleegure benadig. toon egter 'n statisties betekenisualle verskil $(p=0,000 \mathrm{~J})$ op $n 1 \%$ betekenispeil.

Die PAVS-instrument het egter getoon dat daar in vier yan die sewe verplegingseenhede meer verpleegpersoneel benodig word. Die gehalte van die verpleging is nie bepal nie en produktiwite itstudies is mie uitgeafen nie. Hierdie instrument blyk maklik verstaanbaar, bruikbaar en loepaslik te wees en toon 'n hoe interbeoordelingsbetroubaarheid (chronbach alfa-waarde van 0,999).

in Betrowbare PAIS-instrument is ontwerp en suksesvol in 'n navorsingshospitaal geimplementeer. Die vernaamste aambevelings sluit in die nasionale standaardisasie van die PAVS-instrument in hospitale asook die verfyning en uithoetsing van PAVS in ander kliniese areas, bwoorbeeld buitepasiënte en kritieke sorgeenhede. Hierdie instrument behoort dus verder in positiewe bydrae te lewer toi die koste-effektiewe postebepaling in verpleging.

\begin{abstract}
SUMMARY
This study of potient activity level plans (PALP) to determine mursing levels for in-patients wits was carried out by means of an exploratory, descriptive instrumental stuaty within the context of a mursing situation. Alith the literature study serwing as background, a patient activity level plan (PALP) was designed, according to accepted criteria, to find data on which to base past determination for nursing stall.
\end{abstract}

This study was done at a private research hospital in Johannesburg where all the patients and nursing staff firstas well as second-in-charge) were involved. The $P A L P$-instrument was designed by the reseancher, and under supervision of the researcher it was implemented in seven nursing units in the haspital. (The instrument proved to be highly reliable $p=0$,999).

The difference between nursing post determination as recommended and determined by PALP, and nursing post determination as determined by means of a pragmatic subjective approach by the mursing service manager of the hospital, proved to be statistically insignificant. The PALP instrument showed, however, that more norsing staff were needed in four of the seven units. The quality of the nursing care was not investigated nor was a productivity study carried out. The total difference between the recommended and actual nursing hours needed for all the nursing units shows a statistically significant difference $(p=0,0001)$ an a 796 significance level.

The instrument proved to be easily comprehended, easily implemented and relevant to its purpose. It also shows a high inter-rator reliability (a chronbach alpha value of 0.999).

Thus a reliable PALP+instrument was developed and successfully implemented at a research haspital for the determination of nursing posts. The most significant recommendations include national standardization of the $P A L P$-instrument in hospitals and refining and testing of the PALP-instrument in other clinical areas e.g. out-patients and critical care units. This instrument could also contribute towards a more cost-effective past determination in nursing.

\section{INLEIDING}

Dasr is tans verskeic pasientakuutheidsvlakinstrumente (PA VS) van verskeie formate regdeur die Republiek van Suid-Afrika (RSA) ontwikkel en in gebruik. Hierdie PAVS-instrumente stem in beginsel ooreen maar die teenoorgestelde is ook ' $n$ realiteit. ' $n$ PAVS-instrument wat by ' $n$ spesifieke hospitaal in werking gestel is, kry soms byval by ' $n$ verpleegdiensbestuurder van ' $n$ ander hospitaal en word dan sonder die nodige aanpassing(s) by ' $n$ volgende hospitaal in werking gestel. Hierdie praktyk het volgens die Afdeling: Verpleegadviesdienste, Direktoraat: Bestuursadviesdienste van die Transvaalse Provinsiale Administrasie (TPA) heelwat probleme tot gevolg. Alle PA VS word in samehang met 'n kwantifikasiesisteem gebruik. Dit is die berekening van die verpleegsorgtyd of verpleegure van elke groep pasiente. Hiervoor word van hoofsasklik twee metodes gebruik gemaak. Die een is gebaseer op die gemiddelde verpleegure vir elke geïdentifiseerde kategorie en die ander op slandaardtye vir spesificke verpleegprosedures.

Sou die PAVS anvanklik nie met ' $n$ kwantifikasiesisteem ontwikkel word nie, sal 
dit die verpleegkundige personeelbepaling/beraming nadelig beinvloed en sal die gehalte van die verpleging daardeur nadelig geraak word. Sedert 1982 word slegs die Kommissie vir Administrasie-riglyne vit verpleegkundige personeelbepalings/-beramings vir Staats- en Provinsiale hospitale voorgehou.

Die norm, soos vervat in dié riglyne, is ' $n$ amalgamering van al die verpleegkundige personeelvoor- sieningsnorme wat op daardie stadium in Staats- en Provinsiale hospitale in die RSA van krag was, met die grootste gedeclte vanuit dié van die destydse Transvaalse Departement van Hospitaaldienste. Sou daar na die faktore wat 'n PAVS kan beInvloed, gekyk word, beantwoord die Kommissie vir Administrasieriglyne nie meer aan die verpleegkundige personeelvoorsienings- behoeftes nie. Regverdiging vir hierdie stelling lê in die volgende faktore wat in ag geneem behoort te word:-

- Institusioneel: Die aard en omvang van dienslewering asook die uitleg van die hospitaal speel ' $n$ rol.

- Mediese Departement: Indien die gesondheidsdiens geaffilieer is met ' $n$ mediese skool, kan die omvang van die verpleegfunksie daardeur beìnvloed word.

- Verpleegdiens: Indien die hospitaal 'n kampushospitaal vir verplecgopleiding is, kandie verplegingsinteraksies/ verpleegaktiwiteite van die geregistreerde verpleegkundige verskil van dié van haar eweknie by ' $n$ nie-opleidingshospitaal.

- Pasiéntpopulasie: multikulturele, stedelike en plattelandse faktore is bepalend ten opsigle van die akuutheidsvlakke van pasiente (Rowland \& Roland, 1980:401; van Wyk, 1989).

Voorts word gevind dat die huidige probleme wat verpleegdiensbestuurders met PAVS ondervind, oreenstem met dié soos gelys deur Giovannetti en Mayer ten opsigte van die implementering van ' $n$ nuwe PAVS, naamlik weerstand, gebrek aan betroubaarheid, kullery, probleme om verpleegpersoneel te motiveer, spanning onder personeel weens hoe werklading, finansiele probleme, swak beplanning en swak beheer oor die situasie (Giovannetti \& Mayer, 1984:31; van Wyk, 1990).

Tans word die PAVS slegs vir binnepasiente gebruik en word die buitepasiente buite rekening gelaat. Buitepasiente aktiwitejte was nog altyd 'n klein komponent van 'n gesondheidsdiens, maar vandag, met die groter $\mathrm{klem}$ wat op gemeenskapsdienste geplaas word, word dit van al hoe groter belang. Ambulante pasiënte se behoeftes verskil egter grootliks van dié van binnepasiente. " $n$ Sisteem vir die klassifikasie van buitepasiente word deur Hoffman en Wakefield (1986: 23-36) voorgestel
Die grootste kritiek wat teen die meeste PA VS-instrumente ingebring kan word, is dat hulle nie omvattend genoeg is nie en slegs op fisiese aktiwiteite konsentreer terwyl die psigososiale aspekte buite rekening gelaat word. Die intensiteit van die omvang van die verplegingsinteraksie word dus nie ten volle aangespreek nie (Kruger, 1984:31; van Wyk 1990).

Daar is dus ' $n$ behoefte aan ' $n$ geformaliseerde PAVS wat teenoor die huidige gestandaardiseerde verpleegnorme vir verpleegkundige personeelvoorsiening in beide die openbare en privaathospitale gebruik kan word. Muller (1989:385) spreek die hoop uit dat ' $n$ bepaling van PAVS uitgetoets word

Muller (1989:384) stel 'n verpleegdiensstandaard voor wat soos volg lees: "Daar is ' $n$ wetenskaplike gefundeerde stelsel waarvolgens ' $n$ behoefte aan verpleging volgens gedemonstroerde pasientbehoeftes, toepaslike verpleegtussentredes en prioriteite van verpleging behaal word". Sy stel verder ' $n$ standaard voor wat vereis dat pasientakuutheidsvlakke bepaal moet word, ten einde gehalteverpleging en personeeltevredenheid te bevorder

Die vraag ontstaan dus wat die aard van hierdie PAVS moet wees, wat die kriteria vir die seleksie van die PA VS behoort te wees en watter riglyne vir die kategorisering van pasiente geldig sal wees vir benutting deur verpleegkundiges en enige algemene gesondheidsdiens?

\section{DOELSTELLING}

Die doel met hierdie studie is die formalisering van ' $n$ PAVS vir verpleegkundige personeel. voorsieningsdoeleindes deur middel van:

- Die ontwerp van 'n PAVS vir algemene verpleegpraktyk in 'n privast hospitaal in Johannesburg;

- Die formulering van kriteria vir die seleksie van 'n PAVS;

- Die formulering van riglyne vir die kategorisering van pasiente;

- Die ontwerp van ' $n$ verpleegbestuurdersinstrument ten opsigte van verpleegkundige personeel-voorsiening.

\section{OMSKR YWING VAN KONSEPTE}

Pasientgroepering, -klassifikasie, -indeling, -kategorisering en pasientakuutheidsvlakplan het vir die doel van hierdie studie dieselfde semantiese betekenis.

\section{Pasiēntakuutheidsvlakpian (Patient Activity Level System)}

Pasientakuutheidsvlakplan is die sistematiese identifikasie en waardebepaling of -beraming van geindividualiseerde verplegingsbehoeftes van 'n groep pasiente oor ' $n$ tydsverloop (Gillies, 1989: 290, Lewis \& Carini, 1984: 51).

\section{Verpleegkundige Persóneelvoorsiening}

Verpleegkundige personeelvoorsiening is die proses waardeur verpleegdiensbestuurders verseker/toesien dat die regte aantal en kategorie verpleegkundige personeel, aan die regte verpleegeenheid, op die regte tyd toegewys/voorsien word om op ' $n$ verantwoordelike wyse effektief verpleegaktiwiteite ten uitvoer te bring wat aan die behoeftes van pasiente sal beantwoord.

Die kwantitatiewe sowel as kwalitatiewe behoefte aan personeel ten opsigte van gesond- heidsdiens word bepaal volgens gemeenskapseise (Andrews, 1987: 29-30; Gruneberg, 1979: 9).

\section{Direkte Verplegingsinteraksie}

Direkte verplegingsinteraksies is alle verpleegaktiwiteite wat in die gesondheidsdienseenheid waarin die pasient verkeer, plaasvind.

\section{Indirekte Verplegingsinteraksie}

Indirekte verplegingsinteraksies is alle verpleegaktiwiteite wat buite die gesondheidseenheid waarin die pasient verkeer plaasvind maar wat direk met die pasient in verband staan, soos byvoorbeeld samesprekings met die geneesheer of ander paramediese personeel, verband. en behandelingskameraktiwiteite, verpleegdiensbestuurderrondtes, verslag lees en dokumentering van verpleegtussentredes (Amdt \& Hukabay, 1980: 240)

\section{Totale Verplegingsinteraksie}

Totale veplegingsinteraksie beteken dat ' $n$ pasient tydens enige gegewe tydperk van een verpleegkundige andag ontvang insluitende medikasie, onderrig, higiěne, kontrolering van vitale tekens, behandeling ensovoorts (Warstler, 1974: 2).

\section{Professionele Verpleegkundige}

'n Professionele Verpleegkundige is ' $n$ geregistreerde verpleegkundige by die Suid Afrikaanse Raad op Verpleging en sluit alle posklasse vanaf verpleegkundige tot direkteur van verpleegdienste in.

\section{Verplegingseenheid}

'n Verplegingseenheid is ' $n$ geografiese area in ' $n$ hospitaal/gesondheidsdiens vir verskeie pasiente waarbinne direkte- en indirekte verplegingsinteraksies deur verpleeg. personeel ten uitvoer gebring word Verplegingseenheid/afdeling/gesondheidsdi enseenheid en saal word as sinoniem in hierdie studie gebruik. 


\section{NAVORSINGSONTWERP EN \\ KONSEPTUELE RAAMWERK}

Die doelstellings met hierdie ondersoek is soos volg verantwoord:

- 'n Literatuurstudie oor PA VS is gedoen ten einde die omvang en jongste stand daarvan te bepaal vir insluiting in ' $n$ wetenskaplike verpleegkundige postebepaling:

- 'n Verkennende, beskrywende instrumentele studie is binne kontekstuele verband uitgevoer,

- Persoonlike begeleiding vir implementering is deur die navorser gedoen;

- Onderhoudsvoering met verpleegdiensbestuurders, verpleegspesialiste en verpleegadviseurs (Organisasic- en Werkstudiebeamptes) is onderneem om die inhoudsgeldigheid van die PAVS te bepaal.

\section{POPULASIE EN}

\section{STEEKPROEFBEPALING}

\section{Teikenpopulasie}

Die teikenpopulasie in hierdie studie is beperk tot hospitaalpasiente en hospitaalverpleegkundiges in privaathospitale in Suid-Afrika.

\section{Steekproefpopulasie en steekproefbepaling}

'n Privaatgesondheidsgroep - met agt hospitale wat oor die RSA versprei is - is as steekproefpopulasie geselekteer. Hierdie seleksie is op toeganklikheid gebaseer. Die navorser is genader om PAVS in een van hul hospitale in Johannesburg te implementeer.

\section{Organisasie}

'n Privaathospitaal in Johannesburg is geselekteer. Doelgerigte en geriefliksheidseleksie is uitgevoer gegrond op die volgende:-

- die toeganklikheid van die hospitaal vir beide die navorser en die privastgroep se verpleegkundige konsultant;

- bereidwilligheid van die hospitaalgroep om die finansiěle kostes (uitgawes) vir die implementering van PAVS te dra:

- die beskikbaarheid van rekenaardienste by die hospitaal/hospitaalgroep

Die organisasie wat vir die navorsing in hierdie studie gebruik is, is ' $n$ algemene privast gesondheidsdiens wat hulle ten doel stel om kuratiewe gesondheidsdienste aan die gemeenskap wat hulle bedien, te bied. Hierdie hospitaal is deur die bestuur van die gesondheidsdiens vir die implementering van PAVS geselekteer en beskik oor 180 beddens
Hierdie hospitaal vergelyk goed met ander privaathospitale in die omliggende gebied. Ook vergelyk dit met provinsiale hospitale in Transvaal wat volgens die KVA in gemeenskapshospitale klas I ( $1-120$ goedgekeurde beddens) en klas II (120-350 goedgekeurde beddens) gekategoriseer is. Volgens die gesondheidsfasiliteiteplan van die Departement: Nasionale Gesondheid en Bevolkingsontwikkeling (1984:20), voldoen hierdie hospital ook aan die vereistes van ' $n$ streekhospitaal aangesien daar benewens algemene praktisyndienste ook basiese spesialisdienste soos algemene chirurgie, interne geneeskunde, pediatrie, verloskunde en ginekologie hier voorsien word

\section{Verpleegkundige populasie}

Alle verpleegkundiges-in-bevel van verplegingseenhede tydens die dataversamelingsperiode is outomaties by die studie ingesluit, asook dic hospitaalgroep se verpleegkundige konsul tant.

Ten opsigte van die verpleegkundiges is die volgende variante waargeneem

\section{- Kwalifikasies}

- Ondervinding

- Aanstellingsooreenkoms

- Ouderdom

- Geslag

- Bevolkingsgroep.

Vir die bepaling van interbeoordelingsbetroubaarheid van die instrument is die verpleegkundiges- tweede-in-bevel van elke verplegingseenheid ook by die studie betrek.

\section{Verplegingseenheidspopulasie}

Alle verplegingseenhede in die navorsingshospitaal is by die studie ingesluit.

\section{Pasiēntpopulasie}

Alle pasiente wat gedurende die dataversamelingstydperk vanaf A pril 1990 to Oktober 1990 by die navorsinghospitaal in die gemelde verplegingseenhede opgeneem is, is by die studie ingesluit. Alle pasiente is privaatpasiente van wic dic finansiele implikasie van hul hospitalisasie gedra word deur:

- mediese hulpskema/fonds

- die pasiènt self,

- envof 'n derde party

Die omvang van die pasientprofiel by hierdie hospitaal is omvattend en sluit alle bevolkingsgroepe, geslagte, ouderdomsgroepe, gelowe en kulture in. Beide lang-en korttermynpasiente se verplegingsinteraksies is in die studie geakkommodeer

\section{KONSEPTUELE RAAMWERK}

\section{Standaardverplegingsinteraksietye}

Volgens Gillies (1989: 292, 295-296) moet standaardverplegingsinteraksietye bepaal word waar PAVS deel van die verpleegkundige postebepaling is. Hierdie standaard. verplegingsinteraksiestye is bepaal deur middel van tyd- en bewegingsstudies van alle verplegingsinteraksies wat tydens die pasientakuutheidsvlakinstrumentontwerp geidentifiseer is. Hierdie tye (dag en nag) is na ' $n$ gemiddeld vir elke verplegingsinteraksiedissipline en geslag verwerk.

\section{PAVS-sleutel}

Hierdie is ' $n$ sleutel vir die bepaling van pasientakuutheidsvlakke wat wissel van sel fsorg tot intensiewe verplegingsinteraksies, ooreenstemmend tot die volgende vyf elemente (funksionele kategoriec) van verplegingsinteraksies, naamlik:

- fisiese aktiwiteite

- observasies,

- modikasie,

- behandeling

- onderrig en ondersteuning (voorligting en opvoeding).

Hierdie vyf elemente of funksionele kategoriec word elk onderverdeel in subelemente wat die omvang van elk van die elemente definieer. ' $n$ Numeriese waarde is aan elk van hierdie genoemde vyf elemente op ' $n$ skeal van een tot vyf toegeken. Die finale verrekening of somtotal van hierdie vyf numeriese elementwardes sal die pasientakuutheid aandui

\section{PA VS-dokumenteringsblad}

Ten einde ' $n$ logiese en gesistematiseerde dokumenteringsaksie daar te stel is ' $n$ PAVS-dokumenteringsblad ontwerp waarop die toekenning van numeriese waardes per akuutheidselement gedoen kan word. Hierdie blad is ' $n$ werksdokument wat die betrokke verpleegkundige in staat stel om die finale pasientakuutheidsvlak deur rekenkundige verrekening op 'n skaal van oen tot 25 te bepaal (vergelyk figuur 1). Die PAVS-dokumenteringsblad maak nas die individuele akuutheidsvlakbepaling ook vir ' $n$ opsomming van die totale verploegcen heid se akuutheidsvlakke per geslag voorsiening

\section{PAVS-Personeelratioblad}

Alhoewel hierdie komponent van die PAVS-instrument grotendeels die rekenkundige bepaling van benodigde 


\begin{tabular}{|c|c|c|}
\hline \multicolumn{3}{|c|}{ Fguur 1: Paslöntakuutheidevlakskaal } \\
\hline $\begin{array}{l}\text { NUMERIESE } \\
\text { WAARDE }\end{array}$ & $\begin{array}{l}\text { AKUUTHEIDS- } \\
\text { YAK }\end{array}$ & $\begin{array}{l}\text { VERPLEGINGSINTERAKSIE- } \\
\text { INTENSITEIT }\end{array}$ \\
\hline 1.5 & 1 & Solteorg \\
\hline $6-10$ & ॥ & Hulpverplegingsintoraksio \\
\hline $11 \cdot 15$ & III & Intermediôre verplegingsinter rakesie \\
\hline $16-20$ & $\mathbf{N}$ & Hoisorg \\
\hline 21.25 & $\mathbf{v}$ & Krtiake sorg \\
\hline
\end{tabular}

\section{Rekenarisering}

Aanvanklik is daar nie rekenaarfasiliteite vir verpleegkundige postebepaling by hierdie hospitaal ten opsigte van hiendie navorsing beskikbaar gestel nie.

Tydens die verloop van die implementering van die instrument, het die gesondheidsdiensbestuur goedkeuring verleen dat 'n mikrorekenanrfasiliteit wel vir die verpleegbestuur beskikbaar geatel kan word.

'n Kundige op dio gebied van mikrorekenarprogramering is gekonsulteer. Rekenaarprogram-spesifikasies is opgestel met programmatuur wat al die rekenkundige postebepaling vir die verpleegkundige personeel elimineer, en dus die resultate van die totale bepalingsprosedure verkort en meer ekonomies eftektief stem.

Hierdie verandering in die proses bring mee dat - aangesien alegs een mikrorekenaar beskikbaar is - dear van ' $n$ inskakelstrategie gebruik gemaak is ten einde kosbare verplegingsinteraksietye te bespaar met 'n gevolglike PA VS-telefoniese dokumenteringsblad.

$\mathbf{P}=$ Programleiers
$\mathbf{G}=$ Eenhede vir gevorderde prosedures

$\mathbf{E}$ - Eenhede vir elementêre prosedures verpleegkundige personeel insluit, is pasientakuutheidsvlakke nog steeds betrokke.

Pasientakuutheidsvlakke word nou per dissipline per geslag op ' $n$ PAVSpersoneelratioblad oorgedra en teenoor die standaardtyd vir verplegingsinteraksies (ook verpleeguurnorm genoem) deur rekenkundige verrekening tot die totale aantal verpleegkundige personeel benodig, verwerk. Die totale aantal verpleegkundige personeel benodig word nou verder teenoor die akuutheidsvlakbepaling ingedeel in die hoofkategoriex, naamlik;

- Ptogramieiers/professionele verpleegkundige;

- Eenhede vir gevorderde prosedures/ stafverpleegkundige;

- Eenhede vir elementêre prosedures/ verpleegassistent.

Hierdie kalegorisering van verpleegkundige personeel geskied nou ooreenkomstig die vooraf-bepaalde persentasiebetrokkenheid (\%) van elke kategorie - ten opsigte van die nodige verplegingsinteraksie per pasient per akuutheidsvlak in ' $n$ spesifieke verhouding (vergelyk figuur 2,3 en 4).

Hierdie persentasie-indeling ten opsigte van betrokkenheid van verpleegkundige personeel, ooreenkomstig hul bevoegheid en posvereistes, word dus op pasientakuutheidsvlakke gebaseet wat bydraend is tot beter personeelvoorsiening en -benutting van die onderskeie verpleegkunidge personeelkategoriex.
Figuur 3 : Grafiese voorstelling van die voorgestelde on werkdlke personeolvoorslening an die verplegingecenhede vir dagdiensdooleindes vir con wook

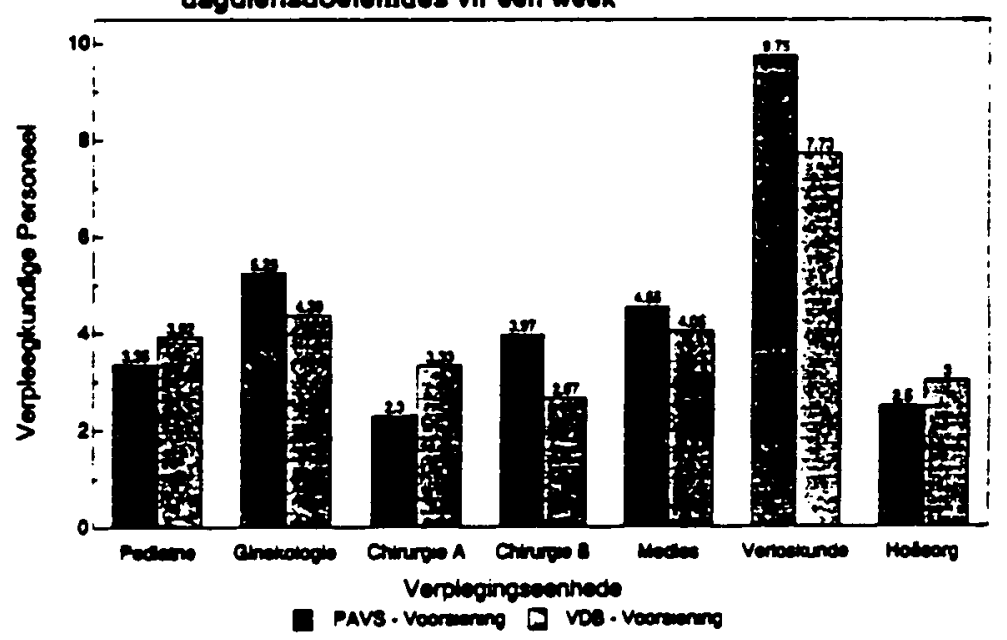

Flguur 4 : Graflese voorstelling ven dhe voorgestelde on wortdlke personeotvoorstening an dle verplegingseenthede vir nagdlensdoeleindae vir een week

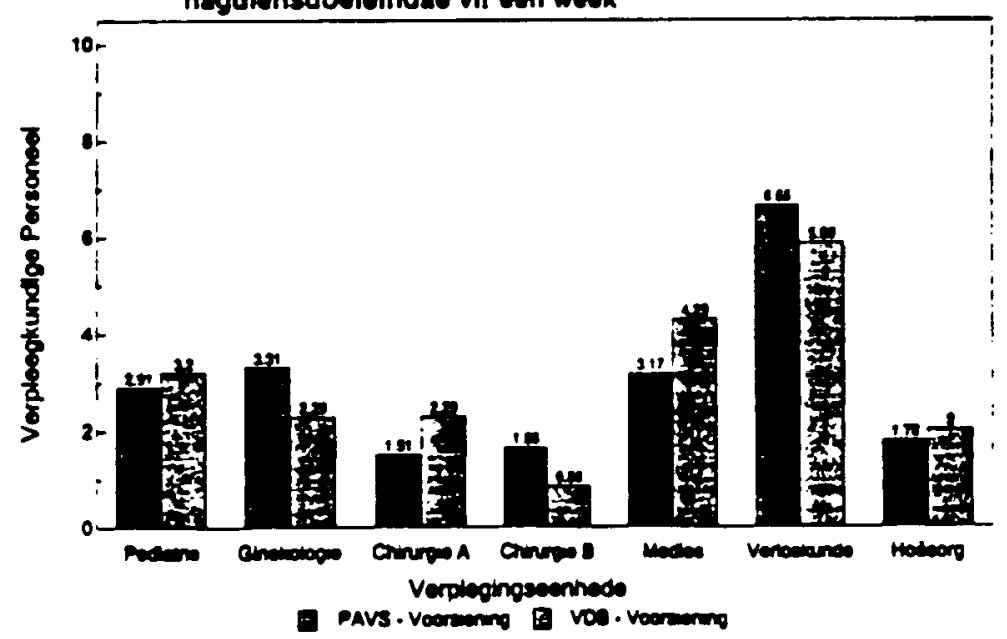




\begin{tabular}{|c|c|}
\hline \multicolumn{2}{|c|}{$\begin{array}{l}\text { Tabel 1: 'n Versprelding van } \\
\text { alfa-waarde In die onderskele } \\
\text { verplegingseenhede met betrekking } \\
\text { tot imterbeoordellingsbetroubaarheld }\end{array}$} \\
\hline $\begin{array}{l}\text { VERPLEGINGS- } \\
\text { EENHEID }\end{array}$ & $\begin{array}{l}\text { ALFA- } \\
\text { WAARDE }\end{array}$ \\
\hline Chirurgie [A] & 0,900 \\
\hline Chirurgie [B] & 0.800 \\
\hline Pediatrie & 0.900 \\
\hline Ginekologie & 1.000 \\
\hline Verloakunde [Moeders] & 1.000 \\
\hline Verloskunde [Babas] & 1.000 \\
\hline Howsorg & 0,000 \\
\hline TOTAN & 0,900 \\
\hline
\end{tabular}

\section{Rekenaaruitvoerstelsel}

Dic eindresultaat van PAVS is ' $n$ rekenaaruitdrukstuk wat aan die verpleegbestuur en verpleegkundige-in-bevel, ooreenkomstig die bepaling van die anvanklike pasientakuutheidsvlakke, die kwaliteite en kwantiteite van verpleegkundige personeel wat vir die betrokke verplegingseenheid benodig word, uitspel.

\section{PAVS-Telefonlese Dokumenteringsblad}

Hierdie komponent van die PAVS-instrument is ontwerp ooreenkomstig die inligting wat ingesamel word soos vervat in die PAVS-dokumenteringsblad. Die PAVStelefoniese dokumenteringsblad word deur die verpleegkundige personeellid (hoofverpleegkundige) wat die mikrorekenaar beman/ hanteer, voltooi soos wat verskillende verpleegeenhede PAVS voltooi en inskakel. Hierdie blad word in alle verpleegeenhede vir dag. sowel as nagdiens benut. Die hoofverpleegkundige sleutel vanaf hierdie brondokument die data in die rekenasr in met 'n volledige verpleegkundige postebepaling vir elke verplegingseenheid wat aan die betrokke behoeftes van elke verplegingscenheid sal voorsien as eindresultaat

\section{RESULTATE}

\section{Steekproefrealisasie}

'n Privaat-gesondheidsgroep met agt hospitale, wat oor die RSA versprei is, is as steekproefpopulasic geselektoer. 'n Hospitaal in Johannesburg is op basis van toeganklikheid vir die navorsing geidentifiseer. In hierdie navorsingshospitaal is " $n$ honderd persent (100\%) steekproef uitgevoer en al die verplegingseenhede is by die navorsing betrek.

\section{Betroubaarheid van die instrument}

Die betroubaarheid van die PAVS-instrument is aan die hand van ' $n$ betroubaarheidstudie gedoen. Vir die doeleindes van so " $n$ studie is ' $n$ instrument vir metingsdoeleindes ontwerp.

\section{Interbeoordelingsbetroubaarheid}

Twee spesifieke verpleegkundiges in elke verplegingseenheid het an die interbeoordelingsbetroubaarheidsbepaling deelgeneem, naamlik;

- die verpleegkundige-in-bevel van elke verplegingseenheid,

- 'n tweede verpleegkundige werksaam in dieselfde verplegingseenheid en wat die nodige indiensopleiding deurloop het en/of wat in die afwesigheid van die verpleegkundige-in-bevel die PAVS hanteer het.

Daar is onderskeidelik ' $n$ A- en B-instrument as genoemde personeel voorsien wasrolgens hul die akkuutheidsvlakbepaling gedoen het. ' $n$ Afsonderlike $A$ - en B-instrument is vir elke pasient gebruik.

Geen bevestiging of bespreking rondom die toekenning van numeriese waardes ten opsigte van die verskillende elemente (funksionele kategoriee) is tydens die betroubsarheids bepaling tussen die twee verpleegkundige personeellede toegelaat nie.
Die instrumente is dasma gesamentlik in ' $n$ koevert wat vir die doel voorsien is, geplaas, geseel en gerdentifiseer deur die verplegingseenheidsnommet en datum op die koevert an te bring.

Dit is sonder versuim an die PAVS-koordineerder versend waar dit deur die navorser afgehaal is.

Alle pasiente wat tydens die verloop van hierdie betroubarheidsbepalingperiode gehospitaliseer is, het deel van die teikenpopulasic uitgemaak. Dic PAVS. koödineerder was verantwoordelik vir die ordelike verloop van die interbeoordelings betroubaarheidsbepaling van die PAVSinstrument.

Die navorser het met die betroubasheidsbepaling/studie ten doel om te verseker dat die PAVS-instrument, wanneer dit benut word vir verpleegkundige postebepaling deur twee verpleegkundige personeellede praktiserend in dieselfde verplegingseenheid, dieselfde eindresultagt sal lewer wat die omvang van die verplegingsinteraksiebehoefte van pasiente akkuraat sal voorspel.

Die interne konsekwentheid van die elemente (funksionele elemente) waarvolgens akuutheidsvlakbepaling geskied, is hoog. Die elemente (funksionele kategoriet) - fisies, observasie, medikasie, behandeling en voorligting/-opvoeding - blyk min of geen probleme te gee nie. Die element onderrig en ondersteuning het geringe verskille in die graderings getoon, maar het egter steeds ' $n$ hot alfa-waarde $(0,999)$ verkry. 'n Algehele alfawarde van 0,999 toon dat dic PAVS-instrument as hoogs betroubaar in die in navorsingshospitaal bewys is

'n Algehele alfa-warde van 0,999 is verkry Die evaluators het slegs verskillende graderings aan die elemente (funksionele kategoriet) - medikasie en onderrig londersteuning in sommige eenhede toegeken Hierdie verskillende graderings was egter

Tabel 2: 'n Vergelyking tussen die totale aanbevole en werkllke verpleegure per verplegingseenheid ten opsigte van dagen nagdiensdoeleindes vir 'n 40-uur-werksweek

VERPLEEGURE PER 40-UUR-WERKSWEEK

\begin{tabular}{|c|c|c|c|c|c|c|c|c|}
\hline \multirow[b]{2}{*}{$\begin{array}{l}\text { VERPLEGINGS- } \\
\text { EENHEID }\end{array}$} & \multirow[b]{2}{*}{ AANBEVOLE } & \multicolumn{2}{|c|}{ DAGDIENS } & \multicolumn{3}{|c|}{ NAGDIENS } & \multirow[b]{2}{*}{$\begin{array}{c}\text { SOMTOTAAL } \\
\text { VERSKIL }\end{array}$} & \multirow[b]{2}{*}{$\mathbf{P}$} \\
\hline & & WERKLIK & VERSKIL & AANBEVOLE & WERKLIK & VERSKIL & & \\
\hline Pediatrie & 200.06 & 235.00 & -34.04 & 174.77 & $102, \infty$ & -17.23 & $-51,27$ & $0,031^{\circ}$ \\
\hline Ginokologie & 441,12 & 368,00 & 73,12 & 227,87 & 102.00 & 35.87 & 108,00 & 0,016 * \\
\hline Chirurgie A & 103.52 & 280.00 & $-86,48$ & 126,53 & $192, \infty$ & $-65,47$ & -151.05 & $0.008 *$ \\
\hline Chirurgie B & 333,08 & $224, \infty$ & 100.08 & 138,18 & $72, \infty$ & 68.18 & 175,20 & $0,002 \ldots$ \\
\hline Madies & 382,50 & $340, \infty$ & 42,50 & 266.25 & 360.00 & $-03,74$ & $-51,24$ & 0.031 \\
\hline Verloskunde & 818,03 & 649.00 & 160.03 & 558.37 & 492.00 & 66,37 & 238.30 & $0.000 \cdots$ \\
\hline Hoersorg & 149,85 & 180.00 & .30 .15 & 108.37 & 120.00 & -13.63 & $-43,78$ & $0.030^{*}$ \\
\hline TOTAAL & 2519,96 & 2276,00 & 243,06 & 1508,34 & 1620,00 & $-21,65$ & 222,31 & $0,001 \ldots$ \\
\hline
\end{tabular}


minimaal. Interbeoordelingsbetroubaarheid in die onderskeie verplegingseenheid word in tabel 1 uitgebeeld.

\section{Akuutheidsvlakbepaling}

In tabel 2 word die totale aanbevole en werklike verpleegure wat per verplegingseenheid vir 'n 40-uur-werksweek ten opsigte van dag- en nagdiens doeleindes benodig en toegeken is, uiteengesit.

Vanuit tabel 2 kan die afleiding/ gevolgtrekking dus gemaak word dat daar ' $n$ noemenswaardige verskil tussen die totale aanbevole en werklike verpleegure vir al die verplegingseenhede ten opsigte van dagdiensdoeleindes 243,96 en nagdiensdoeleindes - 21,65 is. Vir dag-en nagdiensdoeleindes gesamentlik is die verskil 222,3 verpleegure. Hierdie verskil is statisties betekenisvol.

\section{STRUIKELBLOKKE}

Giovannetti en Mayer (1984:31) het 16 probleme gelys wat moontlik tydens die ingebringneming van ' $n$ pasientakuutheidsvlakplan kan opduik. Hierdie gelyste probleme is per nie-gestruktureerde onderhoude met die verpleegdiensbestuur en verpleegeenheidsbestuur bespreek.

\section{Verpleegdiensbestuur}

Die verpleegdiensbestuur het angedui dat tydens die loodstudie daar anvanklik probleme opgeduik het, naamlik:

- daar ' $n$ mate van weerstand teen die PAVS was;

- mocite in die motivering tot die nuwe benadering was:

- spanningsdruk;

- kullery;

- klagtes van personeel dat die PAVS tydrowend is;

- agentskapspersoneel nie die belang van PA VS, veral oor naweke en vakansiedae, soos die permanente personeel ervaar het nie,

- die akkuutheidsvlakbepaling nie altyd op die bepaalde uur (07:00 en 18:00) gedoen is nie.

Bogenoemde probleme is tydens vergaderings waar die verpleegdiensbestuur, die PAVS-koordineerder, verpleegkundige konsultant en die navorser was, aangespreek. Remediering is gedoen met goeie gevolge

Alle probleme is deur die PAVSkoordineerder gelys en tesame met die verpleegkundige konsultant en navorser bespreek en diencoreenkomstig aangespreek en opgelos.

\section{GELDIGHEID}

Die navorser is van mening dat die PAVSinstrument aan die norme van die volgende tipes geldigheid beantwoord, naamlik: siggeldigheid, inhoudsgeldigheid en konstrukgeldigheid binne kontekstuele verband.

Ten einde te verseker dat die PAVS-instrument sal meet wat dit veronderstel is om te meet, is die instrument vir dié doel voorgelê aan verpleegkundiges by openbare hospitale en by die navorsingshospitaal - waar ten minste ' $n$ algemene praktisynsdiens met die spesialisdienste in al gemene chirurgie, interne geneeskunde, pediatrie, verloskunde en ginekologie gelewer word - asook an verpleegdiensbestuurders, hospitaalbestuurders/-superintendente, die verpleegkundige konsultant, verpleegdiensadviseurs, Adjunk- en Direkteure van Bestuursadviesdienste en Verpleegkundige Dienste by die Transvaalse Provinsiale Administrasie se hoofkantoor asook in die gesondheidsdiens waarbinne die navorsing plassgevind het, ten opsigte van die siggeldigheid van die PAVS-instrument. Die siggeldigheid van die instrument is deur al die voorafgaande persone bevestig.

Om die inhoudsgeldigheid van die PAVS-instrument te toets, baseer die navorser hierdie aspek op die literatuur soos vervat in die model wat deur Gillies (1989: 290-293) voorgehou word asook op die werklikheid/ realiteit van kliniese verpleging in Suid-Afrika.

Bevestiging van konstrukgeldigheid is verkry deurdat bewys is dat die PA VS-instrument oor die vermoe beskik om pasiente ooreenkomstig hul behoeftes aan verplegingsinteraksie in verkillende akuutheidsvlakke te klassifiseer. Ook maak die instrument voorsiening vir die akuutheidsvlakwisseling ten opsigte van die elemente of funksionele kategorice op ' $n$ skaal van een tot vyf waarvan die somtotaal dan die finale akuutheidsvlak andui, so ook ten opsigte van die gehalte en kwantiteit van verpleegkundige personeel wat in verskillende verplegingseenhede benodig sal word

\section{GEVOLGTREKKINGS.}

Die navorser wil die volgende gevolgtrekkings maak nadat data verwerk is en resultate vertolk is:-

- 'n PAVS-instrument is vir gebruik in algemene verplegingseenhede in ' $n$ privasthospitasl in Johannesburg ontwerp en suksesvol deur die verpleeg- en cenheidsbestuur benut;

- Hierdie instrument blyk konstrukgeldigheid te hê deurdat dit die behoefte aan verpleegpersoncel akkuraat voorspel. Die verskil tussen die instrument se bepaling (a anbevole) en dié van die verpleegbestuur se pragmatiese voor- spelling (werklike) toon statisties geen betekennisvolle verskille aan nie.

- Hierdie instrument se interbeoordelingsbetroubaarheid is hoog $(p=0,999)$ wat daarop dui dat dit vir die praktisyn in die verplegingseenheid prakties bruikbaar en verstaanbaar is. Daar is egter ' $n$ paar probleme ondervind. :

- Koste-effektiwiteit is bewys aangesien die instrument se resultate die voordele van PAVS verantwoord. Pasientakuutheidsvlakkebepaling neem tussen 20 tot 30 sekondes per pasient en die resultate bepaa die benodigde verpleegpersoneel wat op die dageinde die beskikbaarheid en besteding van die begroting aanspreek

- Die kriteria vir die seleksie van die PAVS is suksesvol geformuleer. Hierdie kriteria se inhoudsgeldigheid is geverifieer deur die literatuur (deduktief) asook deur kundiges (induktien)

- Riglyne vir die kategorisering van pasiente is geformuleer ten opsigte van fisiese, observasie, medikasie, behandeling, voorligting en ondersteuning (funksionele kategoriec of elemente) waraan ' $n$ numeriese waarde gekoppel kon word en waarvolgens die somtotaal die pasiént dienooreenkomstig van die aanbevole personeelbehoefte. Hierdie riglyne verhoog die betroubarheid van die instrument.

- Desentralisering van bestuursverantwoordelikheid het tot op eenheidsbestuursvlak plasasgevind. Personeelvoorsiening is deur die betrokkenheid van verpleegkundiges-in-bevel en tweede-inbevel van verplegingseenhede deur middel van die instrument (PAVS) tot op die laagste vlak, naamlik verpleegeenheidsbestuur, deurgevoer.

- Verpleegpersoneelbenutting is effektief as gevolg van die resultate van die instrument wat verpleegpersoneel ooreenkomstig die bestek van praktyk kategoriser en benut (vergelyk SARV 1985: R387, soos gewysig)

- Giovennetti en Mayer (1984:31) het verskeie struikelblokke by die ontwerp en ingebruiksneming van ' $n$ PAVS geïdentifiseer. Tydens die navorsingsperiode is sommige van hierdie probleme ondervind maar kon vroegtydig - sonder dat dit enige invloed op die resultate van die instrument gehad het - die hoof gebied word. Die gevolgtrekking kan dus, in die lig van die voorgaande, gemaak word dat die nagevorste instrument hox praktiese gebruiksnut het.

\section{AANBEVELINGS}

Die volgende aanbevelings word gemaak

- Dat hierdie pasiěntakuutheidsvlakplan in ander hospitale op nasionale vlak in beide 
openbare sektor- en privaathospitale uitgetoets word.

- Dat pasientakuutheidsvlakplanne ontwerp en uitgetoets word in dic kritieke sorgeenhede van privaathospitale.

- Dat ' $n$ verfyning/aanpassing van die PA VS-instrument in ander praktykareas (buitepasiente, ongevalle, operasiesaal, herstelkamer, primére gesondheidsorgklinieke en psigiatrie) uitgetoets en geimplementeer word.

Indicnsopleiding

Dat 'n PAVS-indiensopleidingsprogram ontwerp, geimplementeer en evalueer word om saam met die instrument op nasionale vlak voorsien te word aan hospitale.

\section{Totale kosteberekening per verplegings- eenheid}

Dat 'n verfyning van die PAVS-instrument deur die insluiting van moontlike kostepakkette wat die verplegingseenheidbedryfskoste per pasient per akuutheidsvlak sal bepaal/weergee, gemaak word

\section{Verpleegonderwys}

Dat pasientakuutheidsvlakplanne benut word ten einde die kliniese personeel se tydsbenutting vir studentopleiding te identifiseer vir optimalisering van teorie en praktyk (gerigte praktykopleiding).

\section{PAVS en gehalteverpleging}

Dat navorsing betreffende die verband tussen personeelvoorsiening soos deur ' $n$ pasientakuutheidsvlakplan bepaal en die gehalteverpleging gelewer, onderneem word.
Produktiwiteitstudies

Dat navorsing betreffende die verband tussen personeelvoorsiening in samehang met produktiwiteitstudies onderneem word ten einde ' $n$ verband te bepaal

\section{SLOTOPMERKINGS}

' $n$ PAVS is ontwikkel en voldoen aan die vereistes van geldigheid en betroubaarheid en blyk ' $n$ hoe gebruiksnut vir binne pasiente te hế.

\section{ERKENNING}

Die navorsers wil die bestuur en verpleegpersoneel van die navorsingshospitaal vir al hul insette en entoesiasme bedank. Dank aan Lennons Pharmaceutical (Pty) Litd vir hul finanséle steun.

\section{VERWYSINGS}

Arndt, C \& Hackabay, LMD (1980): Nursing administration. London Toronto: St Lewis.

\section{DEPARTEMENT VAN GESONDHEID} EN WELSYN, (1984): Gesondheidsdiensfasiliteiteplan. Pretoria: Departement van Gesondheid en Welsyn

Gillies, DE (1989): Nursing management - a system approach. Philadelphia: WB Saunders Company.

Giovannetti, P \& Mayer, GG (1984): Building confidence. JONA, 15(8), 1984: 31-34
Hoffman, F \& Wakefield, DS (1986): Ambulatory care: patient classification. JONA, 16(4), April 1986: 23-30.

KOMMISSIE VIR ADMINISTRASIE, (1982): Handleiding vir verpleegkundige personeelvoorsiening. Pretoria: Kommissic vir Administrasie, soos aangepas deur TPA: Verpleegadviesdienste (ongepubliseerd)

Kruger, A (1984): Verpleegmannekragbeplanning volgens die pasientklassifikasie sisteem. Curationis, 7(1), Maart 1984: 31-36.

Lewis, EN \& Carini, PV (1984): Nurse staffing and patient classification. Maryland: Aspen Publication.

Van Wyk, AJ (1990): Handleiding vir die gebruik van pasientakuutheids. vlakiinstrument in TPA-hospitale. Pretoria: Transvaalse Provinsiale Administrasic.

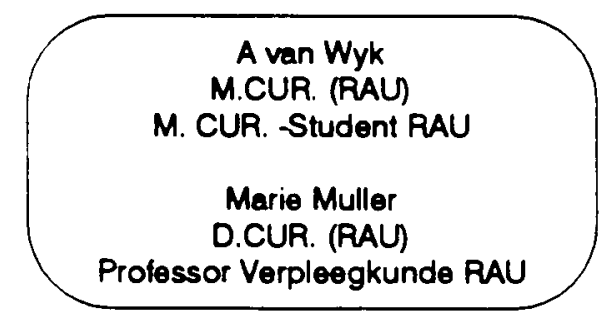

